Recebido: $15 / 12 / 2016$

Aprovado: 23/01/2017

\title{
“Na Ladeira de Dois Mil": o imaginário popular escatológico acerca do ano 2000 em versos de cordéis
}

\author{
Kalliany Moreira Menezes Vitoriano*
}

\begin{abstract}
Resumo: O presente artigo busca analisar, através da literatura de cordel, a crença popular da eclosão do fim do mundo até o ano 2000. Segundo Tavares Júnior (1980: 11-12), a narrativa de cordel, por concentrar as memórias de diversos tempos, seria a "porta-voz" das ideias e dos ideais que circula(va)m no imaginário popular. Dessa forma, seus versos refletiriam a alma do povo nordestino. (Cf. DANTAS, 1978). Além dos folhetos, vasculhamos essa crença através de memórias de devotos e de profecias populares. Destarte, podemos vislumbrar o quão fértil é o imaginário escatológico sertanejo, que ao beber de inúmeras passagens bíblicas, vaticínios de santos e videntes, continua a ser evocado a cada marco temporal ou fenômeno tido como sobrenatural. Isso se faz evidente quando constatamos as longínquas origens das crenças de fim do mundo relacionadas ao ano 2000, que remontam a tradições imemoriais da sagrada família que, passadas de geração a geração, persistiram na memória popular, sendo frequentemente anunciadas e reforçadas pelos profetas e poetas populares.
\end{abstract}

Palavras-Chave: Imaginário; Escatologia; Memória.

\begin{abstract}
This article analyzes, through cordel literature, the popular belief about the advent of the end of the world until the year 2000. According to Tavares Júnior (1980: 11-12), cordel narrative, because concentrating the memories of different times, would be the bearer of ideas and ideals that circulated in the popular imaginary. In this way, its verses would reflect the soul of the Northeastern people. (Cf. DANTAS, 1978). Apart the leaflets, we researched this belief through the memories of devotees and the popular prophecies. Thus, we can perceive how fertile is the eschatological imaginary of the "sertanejo", which is used in innumerable biblical passages, predictions of saints and seers, that they continuing to be evoked to each temporal frame or phenomenons considered as supernatural. All this becomes evident when we perceive the far-distant origins of the end-of-the-world beliefs related to the year 2000, which lead us to the immemorial traditions of the sacred family which, passed on from generation to generation, persisted in popular memory, often being announced and reinforced by the prophets and popular poets.
\end{abstract}

Keywords: Imaginary; Eschatology; Memory.

\footnotetext{
* Mestre em História pela Universidade Estadual do Ceará (MAHIS/UECE). Professora do Curso de Licenciatura Plena em História da Universidade Estadual do Piauí (UESPI), Campus de São Raimundo Nonato. O texto traz passagens da dissertação de mestrado, “'Até mil e tantos, a dois mil não chegarás!': o ano 2000 no imaginário escatológico católico, em Fortaleza (1998-2012)”, financiada pela Fundação Cearense de Apoio ao Desenvolvimento Científico e Tecnológico - Funcap. E-mail: kalliany_menezes@yahoo.com.br.
} 
A Alma do Povo Nordestino em Versos

[...] antes da Ascenção, Nosso Senhor apanhando um leve punhado de areia, disse aos Discípulos: - Até mil e pouco!, e atirou-o ao vento. Nossa Senhora, apiedada do prazo concedido, encheu a santa mãozinha de areia e jogando-a também ao ar, suplicou: - E mais estes, meu Filho! (CASCUDO, 2001: 407, itálico do autor)

Segundo Câmara Cascudo (2001: 405), os fiéis viveriam "essa dádiva suplementar da Mãe de Deus”, a quem os brasileiros dedicariam “a devoção mais profunda e popular." Tal profecia seria atualizada à medida que esses mil e poucos se transformavam em mil e tantos. Assim, o título deste artigo, "Na ladeira de dois mil”, conjura essa tradição imemorial da Sagrada Família, que ecoaria através de diversas vozes e que persistiria na memória popular, sendo frequentemente evocada e reforçada pelas criações literárias dos poetas populares.

Conforme o mencionado folclorista, esses autores:

[...] astutamente, exploram as constantes impressionistas do gênero: - o fim do Mundo, calamidades trovejantes, prazos cronológicos até o ano 2000, variando os sinais do cataclismo, Sol apagado, Lua negra, mar de sangue fervente, peste, fome, guerra de inquietação, e o comportamento desafiante dos três sexos, sem sossego e juízo. A insistência da produção denuncia a continuidade do consumo e a vivência da aceitação interessada em conhecer as transformações das formulas sedutoras na dispersão. E as modificações temáticas, arauteando o final dos Tempos do Homem. (Ibidem: 451)

O cordelista José Costa Leite ${ }^{1}$, que nos cede uma estrofe sua para intitular esse artigo, faz dessa tradição o mote para sua obra, "A mudança dos tempos na ladeira de mil”. O poeta, - que nasceu na Paraíba e residiu em Pernambuco desde a tenra infância, sendo seus cordéis muito populares no Ceará -, é um exemplo de como essas crenças circulam e são ressignificadas. Presentes na memória e no imaginário de avós e pais que migraram levando consigo sua fé.

Assim, a literatura de cordel, apesar de ser um impresso, traria as marcas do oral, visto que suas origens encontram-se numa difusa oralidade que se operava na transmissão de histórias que se contavam e recontavam remodeladas e resignificadas pela memória e pela

\footnotetext{
${ }^{1}$ José Costa Leite nasceu, em 27 de julho de 1927, em Sapé (Paraíba). Nunca frequentou a escola, aprendendo a ler soletrando folhetos de cordel. Em 1938, mudou-se com a família para Condado (Pernambuco). Versejava sobre praticamente todos os temas do cordel, além de publicar anualmente o Calendário Brasileiro, almanaque astrológico contendo diversos conselhos práticos, de grande sucesso junto ao público. Em 1976, recebeu o Prêmio Leandro Gomes de Barros, da Universidade Regional do Nordeste (Campina Grande), pelo conjunto de sua obra, talvez a mais extensa da literatura de cordel brasileira. Ao completar 80 anos, em 2007, foi homenageado na Paraíba recebendo o título de Patrimônio Vivo de Pernambuco. (RAMOS, 2011).
} 
escrita que trataram de selecionar o que seria preservado nas crenças e tradições. ( $C f$. CARVALHO, 1998: 264)

Dessa forma, a narrativa de cordel possuiria um caráter acentuado de obra coletiva, plural, pois produzida "pelo concurso de inúmeras 'vozes', vozes do passado, do presente e do futuro, ou melhor da grande voz do tempo único, o tempo do povo" (TAVARES JÚNIOR, 1980: 11-12), assumiria, “em certo sentido, o papel de 'porta-voz’ das idéias e dos ideais que circula(va)m no imaginário. Não um simples reprodutor das crenças, mas a expressão da complexa rede de crenças do imaginário popular" (LOPES, 1994: 11). Então, o cordel refletiria a religião, o imaginário, a alma do povo nordestino, que professaria em sua maioria um catolicismo não ortodoxo. (Cf. DANTAS, 1978: 67-81).

Segundo Tavares Júnior (1980: 56), a atualidade e adaptabilidade do folheto à cultura do Nordeste decorreriam exatamente da força do mito, que deitaria profundas raízes na alma humana e jamais perderia seu toque de perenidade, pois:

[...] o mito acompanha e acompanhará o homem, enquanto homem for. Indissoluvelmente presa às suas estruturas psíquicas, premoldam os arquétipos primeiros, como confirma a universidade dos símbolos, que nomeiam sua manifestação, que se exterioriza no discurso do sonho, das religiões, da arte e das ideologias, nas expansões do imaginário. (Idem)

Destarte, conforme Gilmar de Carvalho (1998: 263), a literatura de cordel se apresentaria como valioso reforço aos mitos e às expansões do imaginário, como as profecias, que por sua vez buscariam dar respostas aos leitores em relação às expectativas quanto ao futuro. Ainda, de acordo com o autor, elas teriam:

[...] um caráter apaziguador, pela antecipação e decifração do destino, como os antigos oráculos, embora algumas delas possam pretender atemorizar, com resquícios de uma linguagem herdada da Missão Abreviada ${ }^{2}$, suma dos ensinamentos que os pregadores deveriam traduzir e diluir para os códigos sertanejos. (Ibidem: 77)

O cordelista José Costa Leite ([s/d]: 6), em "A mudança dos tempos na ladeira de mil" reúne alguns desses pregadores, os nossos "Nostradamos cabocos", que tanto inspiraram esse imaginário materializado em versos.

\footnotetext{
${ }^{2}$ O devocionário Missão Abreviada foi escrito pelo padre oratoriano português Manoel José Gonçalves Couto (1819-1897), em 1859. Foi o livro mais editado, em Portugal, durante o século XIX. O devocionário constituiuse numa espécie de manual iniciático de rituais, orações e interpretações da Bíblia. As Missões Populares apoiaram em seus ensinamentos na segunda metade do século XIX. Essas Missões introduziram uma concepção de vida religiosa baseada num profundo ascetismo, na visão apocalíptica do mundo, assim como nas práticas de penitência e abstinência. ( $C f$. COUTO, 1868; MELO, 2004: 29-40).
} 
Frei Vital da Penha disse [...]

Nostradamus também fez [...]

O padre Cícero falou [...]

E Frei Damião avisou [...]

Nada de bom se espera

Na Ladeira de Dois Mil.

O poeta Abraão Batista, ${ }^{3}$ por exemplo, no cordel "As profecias do Padre Cícero", escrito em 1971, visando dar mais credibilidade a seu escrito, busca reconstruir a fala do Padre. No entanto, ele deixa em todo o texto as suas marcas autorais, como quando correlaciona o seu (coletivo) temor das explosões nucleares e suas conseqüências apocalípticas com os três estrondos e as três noites de escuro. (Cf. CARVALHO, 1998: 79-80)

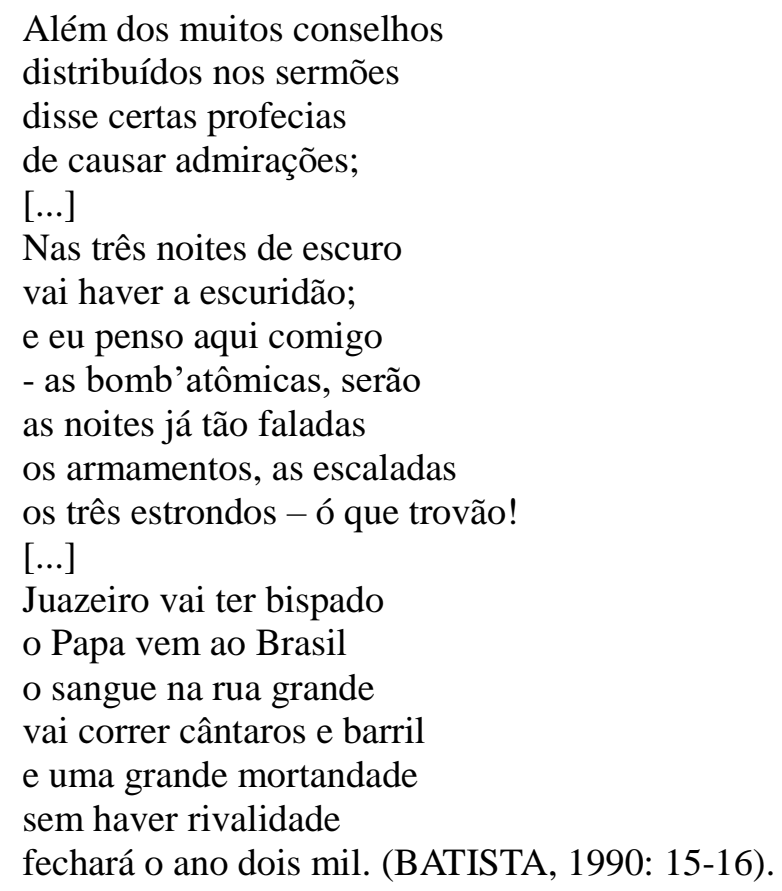

Dessa forma, os cordelistas, como estratégia de convencimento, legitimam "as suas crenças e narrativas ao colocar personagens amplamente reconhecidos como o Padre Cícero como a fonte das informações, das profecias, das revelações" (LOPES, 1994: 43).

Padre Cícero e a "Machadinha de Noé"

Padre Cícero Romão Batista (1844-1934), o fundador de Juazeiro do Norte, chegou ao

\footnotetext{
${ }^{3}$ Abraão Batista, o grande intérprete do Padre Cícero, nasceu em Juazeiro do Norte, Ceará, em 4 de abril de 1935. Bioquímico, foi professor público universitário em Barbalha (Ceará). Começou a escrever folhetos em 1965. Poeta de produção densa e gravador, suas obras são todas ilustradas por ele próprio. Como gravador não se filiou a nenhuma escola, o que torna sua obra inimitável. (Cf. CARVALHO, 1998: 150; ABB, 2010).
} 
povoado com a intenção de partir, em breve, com destino a Fortaleza, a capital do Ceará, onde planejava regressar como professor do Seminário Diocesano, onde fora ordenado em 1870. (Cf. DELLA CAVA, 1985: 25-26). Contudo, um sonho, meio visão e devaneio, mudou seu destino e iniciou sua trajetória mística que seria marcada por muitos sonhos, visões e profecias. Nesse sonho Padre Cícero teria visto Jesus Cristo e os doze apóstolos entrarem no recinto em que encontrava e tomarem assento, reconstituindo a Santa Ceia. Então, numa espécie de antevisão, aos romeiros que acorreriam a Juazeiro do Norte depois de 1889, uma leva de retirantes nordestinos também entra e Cristo dá a missão ao Padre de tomar conta deles. (Cf. CARVALHO, 1998).

Com o "Milagre de Juazeiro" (1889), tido como um sinal dos últimos tempos, a devoção ao Padre se irradiou pelo Nordeste inteiro e transformou Juazeiro do Norte em uma cidade de peregrinações permanentes. (Idem). Uma "Nova Jerusalém" se formava à espera do retorno de Cristo, que, aliás, conforme o historiador Ralph Della Cava (1985: 138), baseado em um relatório confidencial escrito em 1903, "por duas vezes o povo acorreu na expectativa do advento: por duas vezes sua chegada foi adiada". Mesmo assim, a espera continuou e continuaram a (re)produção, a circulação e a distribuição das crenças e profecias em torno de Padre Cícero. (Cf. LOPES, 1994: 41).

Todavia, segundo Eduardo Hoornaert (apud CAMPINA, 1985: 8), Padre Cícero não deixou escritos sua doutrina e nem seus pensamentos. Parece ter apenas repetido ao povo, à sua maneira, a tradição doutrinal e moral do catolicismo de seu tempo. Entretanto, nas narrativas dos devotos, Padre Cícero seria portador de um discurso repleto, com profecias, previsões e poderes miraculosos. Para o historiador Régis Lopes (op. cit.: 41-42), o chamado "Movimento de Juazeiro" seria "muito mais um exercício do imaginário religioso do sertão do que uma simples conseqüência do discurso do Pe. Cícero". O milagre e a "Nova Jerusalém" antes de existirem "de fato", já existiriam "na teoria, nos sentimentos, no desejo-necessidade de vê-los de perto" (Ibidem: 64).

Portanto, as narrativas dos fiéis contidas em cordéis e nos livros de memórias seriam um registro precioso do imaginário escatológico católico popular. Um exemplo da riqueza dessas fontes são as memórias de Maria da Conceição Lopes Campina, organizadas por Eduardo Hoornaert, no livro "Voz do Padre Cícero e outras memórias". Essas lembranças revelam o que seria a primeira profecia do Padre Cícero, intitulada "A Machadinha de Noé", e “os versos antigos dos primeiros poetas". Segundo a devota, tais versos teria o próprio Padrinho Cícero ensinado na escola da Beata Maria da Luz, em Juazeiro do Norte (Ceará),

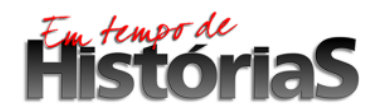


onde sua discípula e primeira superiora do orfanato "Jesus, Maria, José”, Dona Raimunda da Cruz, aprendeu e, por sua vez, repassou às crianças do orfanato. Campina residiu naquela instituição dos 10 aos 17 anos (1922 a 1929). ${ }^{4}$

Para o historiador Hoornaert (apud CAMPINA, 1985: 16), Padre Cícero seria o "visionário do fim do mundo", pois esse tema ocuparia um lugar central em sua doutrina. Aliás, segundo Maria da Conceição Campina (Idem), Padre Cícero anunciava o fim do mundo por três sinais: "a vida dos amancebados e amasiados, o espiritismo e o comunismo". Entendemos que a denúncia desses elementos estaria ligada a uma interpretação baseada nos pressupostos bíblicos, que identificam indícios da proximidade do apocalipse, quando os indivíduos não mais vivem dentro do padrão ideal cristão. (LOPES, 1994: 51-52).

Isso fica claro quando Maria da Conceição Campina (op. cit.: 41) afirma que Padre Cícero condenava o espiritismo como a ciência e a doutrina de Satanás e que devido ao espiritismo, Deus iria castigar as grandes cidades e as grandes capitais que seriam, por sua vez: “destruídas e incendiadas, e transformadas em cinzas e em pó por causa destes pecados de deixar de confiar em Deus para ir atrás de Satanás, confiando no diabo, em seus centros espíritas, viverem do amancebo e do pecado do amasiado". 5

Maria da Conceição Campina, assim como os profetas populares, tem a clara intenção missionária de alertar a sua geração das consequências dos desvios do comportamento cristão, ou seja, para a devota, de 1970 em diante, começariam "os estorvos do fim do mundo" (Ibidem: 23).

De setenta em diante, eu digo, começarão todas estas coisas, porque Deus Nosso Senhor agora vai acabar o mundo dele é de pouco. Que ele se arrependeu de ter acabado o mundo de uma vez. Ele vai acabar é de tampo em tampo é de pedaço em pedaço. Uns cantos com inundação e outros com guerras, outros com a fome e a peste até destruir devagar para dar tempo ao povo se arrepender que o povo do mundo só se endireita é debaixo de castigo. (Ibidem: 94).

Essa citação expressaria à primeira profecia de Padre Cícero. ${ }^{6}$ Ele compararia

\footnotetext{
${ }^{4}$ Esse livro de memórias partiu de uma promessa feita por Maria da Conceição Campina, em 1974, por causa da enfermidade de sua filha. A promessa consistia em escrever tudo que ela soubesse sobre a vida de Padre Cícero e mais cem profecias dele. Os manuscritos podem ser encontrados no Arquivo de Pesquisa psicológico-religiosa da Paróquia de Nossa Senhora das Dores, Juazeiro do Norte, Ceará. (Cf. CAMPINA, 1985).

${ }^{5}$ Segundo Campina (1985: 41), "a lei dos comunistas é o amasiado e o amancebio, que o amasiado é um homem solteiro que se junta com uma moça, estes podem se casar. E o amancebado é um homem casado possuir outras mulheres".

${ }^{6}$ Conforme Maria Campina (Ibidem.: 186-187), ela teria escrito cem profecias do Padre Cícero. Porém, a profecia intitulada "A Machadinha de Noé", ela teria dado aos franciscanos, devido a uma promessa com São Francisco. Contudo, o manuscrito que ainda possuía de tal profecia ela o teria perdido. Outra profecia, Padre
} 
tradicionalmente sua época com os tempos de Noé (Mateus 24. 37-39). Da mesma forma, os devotos igualavam o padre com o profeta, quando o mesmo avisava o povo do perigo: "mas eles tomaram Noé foi em mangação dizendo aquilo é um doido; mesmo assim muitos dizem com meu padrinho Cícero, chamando ele de padre velho caduco, mas ele fez profecia foi pelo Apocalipse de São João Evangelista" (Ibidem: 16-17). Contudo, diferente do fim do primeiro mundo esse acabaria aos poucos, aos "pedaços".

As previsões, em ordem cronológica, buscando apaziguar ou atemorizar, constituiriam um dos modelos mais frequentes desses folhetos proféticos. (Cf. CARVALHO, 1998: 80). Citemos alguns exemplos recorrentes que adiam e atualizam esses prazos cronológicos, mas que, porém, giram em torno do ano 2000.

Apolônio Alves dos Santos ${ }^{7}$, em "Profecias do Padre Cícero Romão até o ano dois mil”, também relaciona as previsões com um sermão que teria sido proferido pelo Padre, tendo, porém, como ponto de partida o ano de 1940. (Idem)

O cordelista Francisco Sales Arêda ${ }^{8}$, em "Um aviso de frei Damião e os sinais do fim dos tempos", descreve o sermão que o capuchinho italiano teria proferido em Nova-Cruz (PE) para mais de duas mil pessoas. Tal folheto revelaria um segredo contado em sonho por Padre Cícero ao seu sucessor, segundo a crença popular. ${ }^{9}$ Esse mistério revisaria o prazo da profecia, que iniciaria agora em 1986:

\author{
80 ainda é bom \\ 86 vai-se ver \\ $\mathrm{O}$ alimento faltar \\ Até água pra beber \\ Gente assar taco de couro \\ Molhar com água e comer. (ARÊDA, [s/d]: 5)
}

Já no folheto de Costa Leite e Enoque José de Maria, “A voz de Padre Cícero”, esse tempo fatídico de conversão e punição é mais uma vez atualizado:

Cícero teria revelado ao senhor José Chaves, que, por sua vez, entregou a devota, juntamente com uma revelação do Frei Vital. Essa última, no entanto, também teria desaparecido.

${ }^{7}$ Apolônio Alves dos Santos nasceu em Serraria (PB), em 20 de setembro de 1926. Aos 20 anos começou a escrever cordéis. Contudo, trabalhou na construção civil de 1950 a 1960, no Rio de Janeiro e na construção de Brasília. Passou seus últimos anos em Guarabira (PB), falecendo em 1998, em Campina Grande. Escreveu cerca de 120 folhetos. Cf. APOLÔNIO..., 2016.

${ }^{8}$ Francisco Sales Arêda nasceu em 1916, em Campina Grande (PB). Em 1927, mudou-se para Caruaru (PE), onde atuou como cantador de viola de 1940 a 1954, quando passou a se dedicar à poesia de composição. Faleceu em Caruaru (PE), em 2005. (Cf. PINTO, 2016a).

${ }^{9}$ Segundo Gilmar de Carvalho (1998: 53), Pio Gianotti, mais conhecido como Frei Damião, missionou no Nordeste brasileiro, a partir de 1931. 
De 90 até 2000

Do Brasil ao estrangeiro

O povo tem que sofrer

No maldito cativeiro

Da praia até o sertão

Vai se ver revolução

Que abala o mundo inteiro. (LEITE; MARIA, [s/d]: 3)

Dessa forma, o fim do mundo apresenta algumas variações que, porém, oscilam dentro de um mesmo fio condutor constituído pelo imaginário escatológico católico:

Disse o bom Deus Sacrossanto:

- Mundo até mil e tanto

Dois mil não há de chegar. (LEITE; MARIA, [s/d]: 3)

No caso acima, o fim do mundo antes de 2000. Para Câmara Cascudo (2001: 452453): "na voz augural dos Nostradamos cabocos. A passagem dos séculos, ou dois zeros sinistros como dois olhos vazios, de cem em cem anos, sugeria admoestações e homilias nas dimensões do arrependimento e do medo julgadores".

Todavia, essas frequentes revisões cronológicas justificariam e reforçariam a ainda não consumação do mundo. Segundo o psicólogo americano Leon Festinger (apud PETRY, 2009: 90), no livro When Prophecy Fails (Quando a Profecia Falha), teríamos a tendência de encontrarmos soluções, mesmo que aparentemente irracionais, para reduzirmos o profundo desconforto provocado por duas informações conflitantes, no caso, a crença de que o mundo vai acabar e a evidência incontornável de que o mundo não acabou. Assim, os fiéis diante de uma profecia fracassada, se aferrariam ainda mais a ela, pois buscariam encontrar um meio de acreditar que a profecia, afinal, estava correta. Nesses casos a explicação mais frequente é a de que as orações foram suficientes para adiar ou amenizar tais vaticínios e possibilitar um maior tempo para a evangelização e os pecadores se converterem e se arrependerem.

Assim, a profecia "A Machadinha de Noé” seria um instrumento de chamamento ao arrependimento e à conversão. O próprio Padre Cícero teria explicado que Deus havia abençoado a machadinha de Noé e quando o profeta batia nos paus fazendo a arca, o machado aconselhava: "te arrepende pecador!" (CAMPINA, 1985: 183). Da mesma maneira o Padre e a devota atualizariam o alerta:

Te arrepende, pecador! Te arrepende, pecador! Te arrepende, pecador! Que o nosso velho mundo já está no fim e já está perto de se acabar, que eu, não é de hoje que aviso. Repare as inundações que têm acontecendo, os terremotos, as guerras aqui, ali e acolá. E as secas e a fome, e as doenças, as epidemias que estão marcadas para acontecer. Tudo isto já está acontecendo. 
O registro mais antigo que encontramos dessa profecia foi o opúsculo "Machadinha de Noé: O aviso de Padre Cícero Romão Batista", que, segundo o folclorista Renato Dantas, ${ }^{10}$ fora escrito pelo cordelista Apolônio Alves dos Santos. Neste folheto, com data de 1911 e publicado em Juazeiro do Norte (Ceará), o autor escreve as previsões de Padre Cícero, que muito se assemelham aos pontos indicados por Hoornaert. Apolônio dos Santos (1911: 1) escreve como se fosse o próprio Padre Cícero e alerta a "todos os habitantes da face da terra" que estaríamos "no tempo do fim do mundo, segundo os sinais preditos por Nosso Senhor Jesus Cristo".

Salientamos, conforme Eduardo Hoornaert (apud CAMPINA, 1985: 8), que em "Voz do Padre Cícero e outras memórias" diversos trechos do texto lembram a formulação da religião católica nos devocionários da época, como: O Catecismo, As Novenas dos Santos e as doutrinas da Missão Abreviada. Na Machadinha de Noé, especificamente, são mencionados, além dos sinais do fim do mundo preditos pelo Cristo, as profecias de São Paulo, Isaías e Daniel. Enunciemos o que prega a profecia atribuída ao Padre, com a indicação de algumas influências entre parênteses:

O princípio das dores de parto (Mateus 24; Marcos 13; Lucas 21): segundo Campina (Ibidem: 223), como já expusemos, estaríamos no tempo do fim do mundo, visto que os sinais preditos por Jesus Cristo seriam evidentes, tais como: pestilência, fomes, nações contra nações, guerras civis, terremotos, inundações e todo tipo de desventura.

Podemos, ainda, observar esse quadro nos versos de José Costa Leite e Enoque José de Maria, que, também, repetiriam as profecias do Padre Cícero:

\footnotetext{
- Meus filhos, está chegando

de uma vez no Brasil

Peste, fome, seca e guerra

Matando o povo sutil

Serão grandes os horrores

Vou falar sobre os clamores

Daqui pra chegar 2 mil.

De 90 por diante

Reina fome e agonia

Pois o sertanejo enfrenta
}

\footnotetext{
${ }^{10}$ Francisco Renato de Sousa Dantas nasceu em Juazeiro do Norte (Ceará), em 23 de março de 1949. Licenciado pela Faculdade de Educação Física da Universidade Federal de Pernambuco. Exerce o magistério em sua cidade natal. Sócio-fundador do Instituto Cultural do Vale Caririense. Dedica-se também a arte teatral. (Cf. SERAINE, 1983: 351).
} 
Fome, crise e carestia

Que chega tremer a terra

Como diz a profecia.

De Pernambuco a Paraíba

Será seco o sertão

No brejo choverá bem

Que dar pra criar feijão

Vê-se muito é carestia

Peste, fome e agonia

E nação contra nação. (LEITE; MARIA, [s/d]: 3)

No aspecto religioso, multiplicar-se-ia a iniquidade e os homens cada vez mais se afastariam de Deus e de sua "Santa Religião Católica". A religião chegaria ao fim em virtude da futura perseguição religiosa implantada pelo anticristo. (CAMPINA, 1985: 223-224)

A revelação referente ao anticristo (Daniel 9.26-27; 1 João 2.18-26; 1 João 4.3; 2 João 1.7) aparece associada à profecia do último papa (São Malaquias e Dom Bosco). Por isso, o anticristo viria como um sacerdote e seu sinal seria o encarnado (cardeal). Para a devota, assim, conversava seu Padrinho Cícero: "morrerão dois papas e um será assassinado pelos próprios cardeais e ressuscitará depois. Mistérios diabólicos! Questão religiosa que se comentará por toda Europa, América e Ásia e a manifestação do Anticristo e a confusão da humanidade naqueles dias." (Ibidem: 224, negrito nosso).

Destacamos, em negrito, as semelhanças da escrita dessa profecia, também presente no opúsculo "Machadinha de Noé: O aviso de Padre Cícero Romão Batista" de Apolônio dos Santos (1911: 2): "morrerão dois Papas e um será assassinado pelos cardeais e ressuscitará depois. MISTÉRIO DIABÓLICO!”. Ressaltamos que mais acima Campina acrescenta apenas a palavra "próprios", o que revela a origem comum desse imaginário. Contudo, não podermos afirmar categoricamente qual realmente seria a fonte, apesar da memória dos devotos, visto que Padre Cícero não deixou escritos. Todavia, interessa-nos aqui saber para além da origem das profecias, que vem a ser as apropriações delas no imaginário de seus propagadores.

Então, tal passagem, também, podemos acompanhar nas estrofes do cordelista Rodolfo Coelho Cavalcante ${ }^{11}$, que segundo o próprio, narra a "verdadeira" profecia do Padre Cícero anunciada em 1933:

\footnotetext{
${ }^{11}$ Rodolfo Coelho Cavalcante se intitulava como trovador popular brasileiro. Nasceu em Rio Largo (AL) em 1919. Começou a trabalhar revendendo cordéis em Parnaíba (PI). Em 1945, passou a residir em Salvador (BA), onde tornou-se defensor e líder da classe de poetas. Distribuía cordéis em todo o Nordeste. Faleceu em 1986. (Cf. PINTO, 2016b).
} 
Em Roma morre dois papas

Um será assassinado

Pelos os próprios cardeais

Um será ressuscitado

Vae haver um prognostico

De um mistério Diabólico

Tenham bastante cuidado. (CAVALCANTE, 1951: 6).

Assim, esse imaginário já estaria impresso em versos antigos dos primeiros poetas populares. Dentre eles, podemos, ainda, destacar o "Sermão de Padre Cícero na Matriz", manuscrito pela devota Maria Campina (1985: 207), que revela influências da profecia dos papas de São Malaquias: ${ }^{12}$

Dizia meu Padrinho Cícero

O nome do derradeiro Papa

É Pedro como o primeiro

Para ninguém se enganar

E quando sair o Anticristo

O mundo vai se acabar.

Entretanto, os cordelistas Costa Leite e Enoque José de Maria identificaram o anticristo não com o encarnado, mas com a "Capa Verde":

Antes do ano 2 mil

Haverá perseguição

Sairá a Capa Verde

Pregando em grande sermão

Oferecendo um tesouro

Dando um rosário de ouro

Por um da religião. (LEITE; MARIA, [s/d]: 4)

Maria Campina (op. cit.: 225-226) acrescenta, ainda, que o anticristo sairia da Rússia (comunista) e espalharia a sua doutrina que seria "o espiritismo e o judaísmo", perseguindo cristãos e israelitas. Ele se declararia ser o Jesus Cristo reencarnado e um terço da humanidade o idolatraria, pois ele faria muitos milagres e sinais sobrenaturais. Assim, dessa maneira, registram os "versos antigos dos primeiros poetas" (apud Ibidem: 209-210):

Se der uma guerra tão grande

\footnotetext{
12, São Malaquias (1094-1148), arcebispo de Armagh e Primaz da Irlanda, foi canonizado, em 1190, pelo Papa Clemente III (1187-1191). Em 1590, entre a morte do breve Papa Urbano VII (13 dias de papado) e o conclave para eleger seu sucessor, Arnoldo Wion (monge beneditino de Monte Castelo) espalhou em Roma o texto latino com a Profecia de São Malaquias. Segundo o monge, elas teriam sido compostas em 1139. A célebre profecia trata de uma lista com 112 papas e antipapas, desde Celestino II (1143-1144) até o (suposto) último pontífice, Pedro II ou Pedro, o romano, que ocuparia o trono do Vaticano no fim dos tempos. (Cf. COELHO, 1983).
} 
Por causa dos comunistas

Que a Rússia declara guerra

Contra o povo de Jesus Cristo

É desta vez que o povo

Dá fim ao Anticristo.

E ele ressuscitará

Com o espírito do diabo [...]

E ele fica governando

Não quer que fale em Jesus

Dizendo: Jesus sou eu,

[...]

Oh eternidade de pena

Os inferno horroroso

Oh fogo da ira de Deus

Oh lugar tenebroso [...]

Outra profecia evocada na "Machadinha de Noé" e repetidamente tratada na literatura de cordel é a "guerra consumidora" (Daniel 11; 1 Tessalonicenses 5.3): "Naqueles dias começará a guerra civil ou consumidora da humanidade. Antes da guerra os povos dirão que há paz e segurança, mas imediatamente sobrevirá repentina destruição (Palavras do Apóstolo São Paulo)" (CAMPINA, 1985: 225). Ela iniciaria na Rússia e se espalharia pelo mundo implantando o comunismo e a perseguição religiosa. No Brasil por pouco tempo seria restaurada a monarquia que terminaria com uma ditadura militar, forma de governo, também, identificada como anticristã. (Cf. Idem).

Já os poetas populares Costa Leite e Enoque José de Maria alertaram, em "A Voz do Padre Cícero", que tais fatos ocorreriam no final de 1998:

\author{
Daqui para o fim da Era \\ Chegará um rei na corte \\ Criando a lei da força \\ Do chicote e do açoite \\ Em vida eu sempre dizia \\ Meus filhos, trabalhem o dia \\ Para comerem de noite. (LEITE; MARIA, [s/d]: 5)
}

Nos manuscritos da beata podemos identificar uma atualização da profecia visto que a grande guerra aparece marcada para acontecer depois do ano de 1930: "Meus caros amiguinhos, aviso a todos que em breve tempo, antes do dia final, o mundo vai ser conflagrado por uma grande guerra e isto ocorrerá depois do ano de 1930." (CAMPINA, op. cit.: 224). Contudo, as duas testemunhas (Apoc. 11.3-13) apenas se revelariam em 1981: 
Olhe o meu aviso! Ninguém se engane, que o tempo é chegado. Cuidem todos em servir a Deus. Porém, meus amiguinhos, muitos não acreditarão neste meu aviso, quando brevemente se arrependerão. Brevemente mandarei circular o meu segundo aviso com relação à vinda de Elias e Enoque ${ }^{13}$ que sairão combatidos pelos ministros de Satanás, que estes sairão no mundo em março de 1981, depois que o Céu fizer sinal. Deus vos guarde. - Padre Cícero Romão Batista. - Fim da Profecia. (Ibidem: 226).

Entendemos que indicar o início da "guerra consumidora" para depois do ano de 1930 reforça a autenticidade da profecia, visto que são "os tempos" de Padre Cícero. Destarte, esse distanciamento também pode demonstrar inicialmente uma tentativa de aumentar a autoridade do teor da revelação ao prenunciar a Segunda Guerra Mundial (1939-1945). Posteriormente, como podemos observar, esse conflito foi e está sendo relacionado a uma futura guerra atômica, a Terceira Guerra Mundial, como bem expressou Abraão Batista, no cordel "As profecias do Padre Cícero”, escrito em 1971.

Tal "guerra consumidora" exterminaria três partes da humanidade, mas os justos seriam salvos no retorno de Cristo, que viria buscá-los: "nos dias destas três letras: X A I X I" (CAMPINA: 1985: 224). Esse mistério assemelha-se ao enigma bíblico do número 666 e ao código empregado em outra profecia atribuída a Frei Vital da Penha (1780-1820) e transcrito pela própria religiosa ${ }^{14}$ : “'Quando vires um V de pernas para cima e outro $\mathrm{V}$ de pernas para baixo e no meio um mostraço e uma tesoura, aí verás a guerra consumidora'. Agora, não sei se é um sinal do céu ou se é nome de pessoa na terra." (Ibidem: 186-187)

Câmara Cascudo (2001: 453) credita a Frei Vital a profecia mais antiga escrita em território brasileiro. Ela teria sido redigida entre 1817 e 1818. Conforme Eusébio de Sousa (1934: 115-120), dariam-na como se fora escrita em 1817, no ano da revolução separatista e republicana de Pernambuco, a qual envolveu um grande número de padres e frades. Contudo, segundo Della Cava (1985: 30), essa profecia foi apenas atribuída ao frei depois de sua morte. A profecia teria circulado por todo o Nordeste "em vastas centenas de cópias secretas, decoradas e ditas em voz alta como versículos inéditos do Apocalipse" (CASCUDO, op cit.: 453). Transcrevemos uma versão da profecia pesquisada pelo Padre Francisco de Luna

\footnotetext{
${ }^{13}$ Segundo Alfaro (2002: 76), as duas testemunhas foram popularmente identificadas com Elias e Enoque, pois esses ainda não teriam sofrido a morte. Elias subirá ao céu em um redemoinho (2 Reis 2.1,11-12) e Deus tomará Enoque para si (Gênesis 5.24).

${ }^{14}$ Capuchinho italiano, oriundo do hospício da Penha no Recife, Frei Vitale de Frascarollo ficou conhecido como Frei Vital da Penha (1780-1820). Conforme Cascudo (2001: 453) era um "capuchinho bradador e fervoroso, pregava o Inferno como estrada para o Paraíso, ameaçando e flamejador numa eloquência de trovoada". Seguindo a antiga tradição capuchinha, carregada de um misticismo profético, o seu discurso escatológico também enfatizava a ira divina e a perdição iminente do homem. Assim. Frei Vital teria contribuido para a geração de um rico escopo de crenças e práticas religiosas escatológicas. (Cf. PAZ, 2004: 9-27).
} 
Tavares (apud HOORNAERT, 2006: 27-30):

\author{
De dois a dois VV, \\ Um de pernas para baixo \\ $E$ outro de pernas para cima \\ Quatro voltas de um compasso, \\ Vai chegando a um ponto \\ De um disforme mortaço; \\ O meio ponto a tesoura \\ Será a guerra consumidora \\ E o tempo será tal que tudo irá afinal. \\ Quando vires o sol escuro \\ Amola a faca para comer couro no futuro, \\ Que na era dos dois XX, \\ Verá rebanhos de vinte mil. [negrito nosso].
}

Provavelmente, essa revelação foi associada ao final do século XX, literalmente a "era dos dois XX”. Para Câmara Cascudo (2001: 454), essa seria a profecia-padrão, pois em sua indecifrabilidade caberiam todas as interpretações e desejos:

\begin{abstract}
É a profecia-padrão, amada pelo Povo porque, nada percebendo, nela cabem todas as interpretações e se aninharão as volições do Interesse. [...] Visível a constante rítmica nos versos soltos, rimados, tendência regular nas profecias populares. A finalística cristã acusa-se pelas desgraças anunciadas, sangue, guerra, brutalidades serem provocações trágicas à oportuna intervenção divina, redimindo os náufragos desditosos. [...] O maior e decisivo efeito da profecia é a sua indecifrabilidade imediata e direta. Enfermidade sofrida por todos os oráculos, indispensando os traduttori-traditori para as infelicidades prestimosas.
\end{abstract}

Da mesma forma, a profecia atribuída a Padre Cícero, "A Machadinha de Noé”, anuncia todas as desgraças e provações àqueles que não se arrependerem de seus pecados. A seguir destacamos uma passagem que resumiria os acontecimentos do final dos tempos. Esses pontos seriam uma cópia, com pequenas variações, do seguinte trecho do opúsculo de Apolônio dos Santos (1911: 3-4):

Naqueles dias será terrível a fome, depois ingressará a peste, o que escapar da guerra ou da espada não escapará da fome, o que escapar da fome, não escapará da peste, por fora assolará a espada e por dentro a fome e a peste. Eis meus caros amiguinhos o fim dos homens neste mundo. Serão destruídas todas as cidades, com todas as riquezas e com todas as glórias, serão reduzidas às cinzas. Eis a ira de Deus todo poderoso, derramada contra os homens, devido ao orgulho e a soberba. A terra ficará deserta e inabitada, o sol escurecerá; a lua não dará mais a sua claridade, porém meus amiguinhos, aqueles que converterem-se e arrependerem-se de seus pecados e buscaram a 
Deus Nosso Senhor Jesus Cristo, destes não perecerá nem um só cabelo da cabeça todos se salvarão destas pragas, só serão participantes delas os maus e ímpios que não se arrependeram para dar a glória a Deus do céu, meus IRMÃOS!

Como podemos observar na citação acima, na profecia "A Machadinha de Noé” a menção sobre o escurecimento do sol é muito sutil e com referência direta às passagens bíblicas (Isaías 13.10, Mateus 24.29, Marcos 13.24). A revelação desse fenômeno foi transmitida oralmente pelos devotos mais antigos de Juazeiro do Norte que, segundo Campina (1985: 152-153), contaram o que Padre Cícero teria anunciado:

O Sol escurece, é com altura de nove horas do dia. Ele volta para trás e sobe uma nuvem negra e escurece. Sobe esta nuvem e cobre todo o céu, e dali por diante a lua e as estrelas não darão claridade. Só que clareia é o sol. Os amancebados correrão para os infernos, virados em bestas, cavalos, jumentos e jumentas, e os demônios dos infernos bem antes do sol limpar, e botar a brita e se montam e os carregam para os infernos, tudo amontados nos pobres amancebados. E nestas três noites é uma zoada tão grande nos becos das ruas das cidades, que parece dez latas batendo, dos gritos dos homens e das mulheres brigando uns com os outros, e se mordendo. E com três dias o Sol limpa, mas dái por diante será uma seca tão grande [...]. E morrem todos os animais de toda espécie, tanto morrem de fome, como morrerem de sede e da peste. E é três anos e seis meses de seca das mais espantosas misérias. E isto é mais aqui no Ceará, nos sertões. Os romeiros da Mãe de Deus vão escapar desta, é nas margens do Rio São Francisco [...].

Esse fenômeno, assim como toda data fatalista, sofreria atualizações e remarcações a medida que não se concretizasse. O cordel "A voz do Padre Cícero", de José Costa Leite e Enoque José de Maria ([s/d], p. 3-4), aponta esses dias de trevas para ocorrerem em 1997:

\author{
No ano 97 \\ A 26 de janeiro \\ Haverá um grande eclipse \\ Visto até no estrangeiro \\ Para complicar o futuro \\ Virão três dias de escuro \\ Escurece o mundo inteiro. \\ Antes do ano 2 mil.
}

Costa Leite ([s/d], p. 5) já em outro folheto, provavelmente mais recente, intitulado "A mudança dos tempos na ladeira de mil", prorroga tal prazo para 1998, mas, ainda, aponta que ocorreria o fim do mundo até o ano 2000.

Em 98, em abril

O povo vê-se em apuro 
Com as 3 noites de escuro

99 vai ser duro

Na Ladeira de Dois Mil.

E, naturalmente, podemos perceber os ecos da profecia do "sol escuro", em agosto de 1999, através de depoimentos, como o de Maria Ana dos Santos (apud DEVOTOS..., 1999), 65 anos, que da mesma forma, teria ouvido das pessoas mais velhas que o Padre Cícero teria dito que "o sol ia nascer e quando desse umas oito horas ia baixar devagarinho e seriam três noites de trevas e de estrondo".

O temor do sol escuro fora confundido e associado ao eclipse solar de 11 de agosto de 1999, previsto pelo profeta Michel de Nostradamus (1503-1566). ${ }^{15}$ Aliás, há muitos anos os cordelistas vinham reforçando o imaginário em torno das centúrias do vidente, como registra o cordel "As profecias de Nostradamus, a morte do papa e o fim do mundo" de Berenice de Souza Lima ([s/d]: 10):
Numa de suas centúrias
Ele escreveu com clareza
O mês de outubro de 99
Como sendo o fim dos tempos
Havendo um grande eclipse
Jamais visto na natureza.
Porém segundo a Ciência
Esse eclipse se dará
Não no mês de outubro
Um pouco antes será
No dia 11 de agosto
As 10 hs. e 28 minutos se dará
Peço aos leitores
Para logo se preparar
Pois notícias propagadas
É, foi ou será
Prepare o seu espírito
Para com o Eterno encontrar.

Essa profecia seria relembrada e reforçada nesse período, pois tal revelação também alertava sobre a passagem de um planeta no sol:

\footnotetext{
15 Michel de Nostredame, "o rei entre os profetas", nasceu a 14 de dezembro de 1503, em Saint-Rémy, na Provença. A família paterna descenderia da tribo de Issachar, uma das doze tribos hebraicas, saídas de Jacó, que seria capaz de discernir e observar os sinais dos céus. Teria iniciado seu aprendizado em ciências ocultas com seu bisavô materno Jean de Saint-Rémy, mas como um bom cristão-novo, Nostradamus teria queimado seus escritos ocultos. Declarou que o seu dom era hereditário e concedido por Deus. Por deliberação embaralhou suas previsões, começando as escrever a partir do ano de 1545. Predisse a própria morte no seu livro Presságios. Faleceu no dia 2 de julho de 1566, em Salon. (Cf. PAIVA, 1990; NASSETTI, 2006: MONTEIRO, 1967).
} 
E quando ouvir os padres avisar que vai passar um planeta no sol muito forte, quem tiver dinheiro, compre logo farinha e guarde, e vá ganhar para ir comprando comida, que o arrocho é do segundo ano em diante. Mas se tomarem os meus conselhos, passa sem sacrifícios, comprando arroz na casca, plantando mandioca e fazendo açudes para o plantio de legumes, batata, feijão, milho e macaxeira. É assim que vocês deviam fazer. (CAMPINA, 1985: 164-165)

O medo do sol escuro, por sua vez, teria reacendido outro temor que habita o imaginário nordestino e se faz mais sombrio no sertanejo, o temor de uma seca apocalíptica, como bem expressa a passagem acima. Nas memórias de Maria da Conceição Campina, Padre Cícero indicou vários meios para sobreviver à última seca do fim do mundo. Inclusive, os cordelistas propagaram uma oração, que inclusive seria de bom alvitre andar sempre com ela, para se proteger dos três dias de escuro:

- Valei-me meu Padim Ciço do Juazeiro, Jesus adiante paz na guia. Me encomende a Deus e a virgem nossa mãe e aos 12 apóstolos meus irmãos. Andarei dia e noite com meu corpo cercado e circulado com as armas de São Jorge não será preso nem ferido nem meu sangue derramado, andarei tão livre como o corpo de Jesus 9 meses no ventre da Virgem Maria. Amém.

Meus inimigos terão olhos e não me verão, boca e não falarão, terão pés e não me alcançarão, terão mãos e não me ofenderão;

Obs.: (Todos aqueles que andarem com esta oração do meu Padim Ciço, estarão livres do inimigo e dos 3 dias de escuro. Para se andar com esta oração não é preciso saber ler e nem escrever, é bastante andar com ela). (COSTA, 1994: 52).

O folclorista Renato Dantas (1976: 32-37), além de narrar com mais detalhes a profecia sobre os três dias de trevas, que ouvira pela primeira vez ainda em sua infância, revela, também, quais seriam os outros meios de se proteger das trevas apocalípticas:

A estória era a seguinte: um dia o sol não nasceria e a terra mergulharia nas trevas. Deus mandava este castigo para a humanidade pagar os seus pecados. Era fato consumado que os amancebados, ladrões, assassinos se transformariam em mulas-sem-cabeça, lobisomens, bestas-feras, zumbis, etc. estes bichos humanos chegariam às portas que não tivessem uma cruz pintada e suplicariam para entrar. Imitariam a voz de crianças a fim de que as pessoas sentissem pena e abrissem a porta, caso o fizessem, as assombrações devorariam os moradores. Apenas as velas bentas dariam luz. A água também benta seria arma contra os malfazejos. Choros, lamentos, gritos, seriam ouvidos por toda parte. O frio seria impiedoso e muitas pessoas morreriam. Quem conseguisse escapar, iria encontrar um mundo maravilhoso. As assombrações ou pecadores seriam julgados e mandados para o inferno. E o sol nasceria com Deus descendo a terra abençoando todos os homens. [negrito nosso].

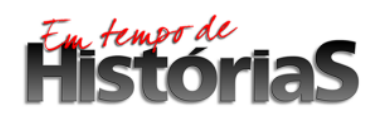


Assim, nessas "estórias" se condensam elementos de várias profecias que foram agregadas à medida que iam sendo contadas e recontadas por diversas vozes ao longo do tempo. Elas revelam os Mythós, na definição própria da palavra grega, como indica Marilena Chauí (2006, p. 124):

[...] o mito é uma narrativa sobre a origem do mundo e dos homens, narrativa cuja origem não pode ser encontrada ou fixada, e cuja existência consiste em desdobrar-se em numerosas narrativas que reiteram a mesma matriz, sem que esta possa ser identificada em um primeiro e único mito. $\mathrm{Na}$ verdade, o mito opera como bricolage, reunindo e colando elementos de diferentes providências cujo arranjo, por repetir a matriz estruturante da narrativa, parece como um todo dotado de sentido [...] [itálico do autor].

Portanto, como bem alertou Câmara Cascudo (1971: 188), não deveríamos nos estarrecer com os milênios, atribuídos às crenças dos nossos dias, pois, segundo Régis Lopes (1994: 23), o mito seria "uma manifestação cultural que guarda um complexo e rico jogo de concepções e sentimentos intimamente relacionados com a (re)produção e circulação do imaginário das coletividades". Portanto, tais revelações seriam palimpsestos de numerosas profecias que continuam a ecoar nas tradições populares e religiosas cristãs. ( $C f$. ELIADE, 1998: 126).

\section{Considerações Finais}

Portanto, nesse artigo podemos vislumbrar o quão fértil e complexo é o imaginário popular escatológico católico, que ao beber de inúmeras passagens bíblicas, revelações marianas e nos diversos vaticínios de santos, padres e videntes, continua ele a ser evocado e ressignificado a cada eclipse solar, marco temporal ou fenômeno tido como sobrenatural, somando-se a outras variadas previsões pseudocientíficas, esotéricas, espíritas, tudo ao gosto do momento.

Crenças essas que, assim como o próprio imaginário, dilatam o tempo em um trânsito contínuo, onde passado, presente e futuro se imbricam. Isso se faz evidente quando constatamos as longínquas origens das crenças de fim do mundo relacionadas ao ano 2000. Elas remontam às tradições imemoriais da sagrada família passadas de geração a geração até se materializarem em versos de cordéis, que, por sua vez, persistiriam na memória popular, sendo frequentemente cantados e atualizados pelos profetas e poetas populares: "Mundo até mil e tanto Dois mil não há de chegar" (LEITE; MARIA: [s/d]: 7).

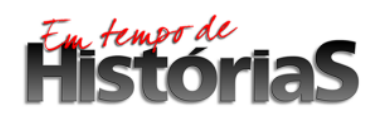




\section{Referências Bibliográficas}

ABB: Abraão Batista. ABLC - Academia Brasileira de Literatura de Cordel, Rio de Janeiro. Disponível em: <http://www.ablc.com.br/gravuras/gravuras.htm>. Acesso em: 28 dez. 2010.

ALFARO, Juan Ignácio. O Apocalipse em perguntas e respostas. São Paulo: Loyola, 2002.

APOLÔNIO Alves dos Santos. O Nordeste. Disponível em: <http://www.onordeste.com/onordeste/enciclopediaNordeste/index.php?titulo=Apol\%C3\%B4nio+Alves+dos+Sa ntos\&ltr=a\&id_perso=1241> Acesso em: 07 dez. 2016.

ARÊDA, Francisco Sales. Um aviso de frei Damião e os sinais do fim dos tempos. [s/d]. 8p. (Coleção de Folhetos de Cordel da Biblioteca Blanche Knopf). Fundação Joaquim Nabuco. Disponível em: <http://www.fundaj.gov.br/docs/text/bib-cordel.html>. Acesso 10 jan. 2011.

BATISTA, Abraão. As profecias do Padre Cícero. 5. ed. Juazeiro do Norte: Biblioteca Nacional do Cordel, nov. 1990.

CAMPINA, Maria da Conceição Lopes. Voz do Padre Cícero e outras memórias. São Paulo: Paulinas, 1985.

CARVALHO, Gilmar de. Madeira matriz: cultura e memória. São Paulo: Annablume, 1998.

CASCUDO, Luís da Câmara. Superstição no Brasil. São Paulo: Global, 2001.

1971.

Tradição, Ciência do povo: pesquisas na cultura popular do Brasil. São Paulo: Editora Perspectiva,

CAVAlCANTE, Rodolfo Coelho. Verdadeira Profecia do Padre Cícero Romão. Salvador, Bahia. 1 jul. 1951, 10p, p. 6. Casa Rui Barbosa. Disponível em: <http://docvirt.com/docreader.net/ DocReader.aspx?bib=cordelfcrb\&pagfis=51639\&pesq=>. Acesso em: 02 dez. 2016

CHAUI, Marilena. Simulacro e poder: uma análise da mídia. São Paulo: Ed. Fund. Perseu Abramo, 2006.

COELHO, Abílio Costa Coelho (redação). Predições e Profecias. Revisão de Manoel Ferreira Paulino e Cláudia de Siqueira Martinelli. Rio de Janeiro: Otto Pierre editores, 1983

COSTA, Gutemberg Medeiros. Profetas do Nordeste. Natal: Clima, 1994.

COUTO, Manoel José Gonçalves. Missão Abreviada: para despertar os descuidados, converter os peccadores e sustentar o fructo das missões. 6. ed. Porto: Tipografia de Sebastião José Pereira, 1868.

DANTAS, Francisco Renato Sousa. Lendas e mitos de Juazeiro e do Cariri. Juazeiro do Norte, CE: Boletim do Instituto Cultural do Vale Caririense, n. 3, p. 32-37, 1976.

Literatura de Cordel: os folhetos do padre Cícero. Juazeiro do Norte, CE: Boletim do Instituto Cultural do Vale Caririense, n. 5, p. 67-81, 1978.

DELLA CAVA, Ralph. Milagre em Joaseiro. Rio de Janeiro: Paz e Terra, 1985.

DEVOTOS de padre Cícero pedem proteção. Diário do Nordeste Online, Fortaleza, 11 ago. 1999. Caderno Regional. Disponível em: <http://diariodonordeste.globo.com/1999/08/11/>. Acesso em: 25 fev. 2006.

ELIADE, Mircea. Tratado de História das Religiões. São Paulo: Martins Fontes, 1998.

HOORNAERT, Eduardo. Crônicas das Casas de Caridade: fundadas pelo Padre Ibiapina. Fortaleza: Museu do Ceará, Secretaria da Cultura do Estado do Ceará, 2006.

LEITE, José Costa. A mudança dos tempos na ladeira de mil. Pernambuco. Produção Independente. [s/d].

LEITE, José Costa; MARIA, Enoque José de. A Voz do Padre Cícero. Pernambuco. Produção Independente. [s/d]. 7p.

LIMA, Berenice de Souza. As profecias de Nostradamus, a morte do papa e o fim do mundo. Caruaru, PE: Gráfica Sabaó Dila e Lima. Fundação Joaquim Nabuco. Coleção de Folhetos de Cordel da Biblioteca Blanche Knopf. Disponível em: <http://www.fundaj.gov.br/docs/text/bib-cordel.html>. Acesso em: 10 jan. 2011.

LOPES, Régis. João de Cristo Rei: o profeta de Juazeiro. Fortaleza: SECULT, 1994.

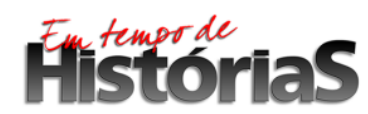


MELO, Rosilene Alves de. O outro Juazeiro: história das crenças e práticas ocultas na cidade sagrada. Tendências: Caderno de Ciências Sociais da Universidade Regional do Cariri. Crato: URCA, v. 2, n.1, p. 29-40, jul. 2004.

MONTEIRO, Mozart. O livro das Profecias: a História, até 1999, em vaticínios autorizados por inúmeros outros, já cumpridos. Rio de Janeiro: Edições O Cruzeiro, 1967.

NASSETTI, Pietro. As profecias: Nostradamus. São Paulo: Martin Claret, 2006.

PAIVA, Marcelo Whately. O pensamento vivo de Nostradamus. São Paulo: Martin Claret, 1990.

PAZ, Renata Marinho. Cariri, campo fértil da religiosidade popular. In: Tendências, Caderno de Ciências Sociais da Universidade Regional do Cariri, Crato, v. 2, n. 1, p. 9-27, jul. 2004.

PETRY, André. O fim do mundo em 2012. Veja. São Paulo: Abril, ed. 2137, p. 90, 04 nov. 2009. Seção Especial.

PINTO, Maria do Rosário. Biografia: Francisco Sales Arêda. Fundação Casa de Rui Barbosa. Disponível em: < http://www.casaruibarbosa.gov.br/cordel/FranciscoSales/franciscoSalesAreda_biografia.html> Acesso em: 02 dez. 2016a.

Biografia: Rodolfo Coelho Cavalcanti. Fundação Casa de Rui Barbosa. Disponível em: < http://www.casaruibarbosa.gov.br/cordel/RodolfoCoelho/rodolfoCoelho_biografia.html\#> Acesso em: $02 \mathrm{dez}$. 2016 b.

RAMOS, Everardo. Biografia: José Costa Leite. Fundação Casa de Rui Barbosa. Disponível em: <http://www.casaruibarbosa.gov.br/cordel/JoseCostaLeite/joseCostaLeite_biografia.html>. Acesso em: 01 ago. 2011 .

SANTOS, Apolônio Alves dos. Machadinha de Noé: aviso do Padre Cícero Romão Batista. Juazeiro do Norte: Gráfica Lira Nordestina, [1911]. 6p.

SERAINE, Florival. Antologia do folclore cearense. 2. ed. Fortaleza: Edições UFC, 1983.

SOUSA, Eusébio de. No tempo de Frei Vidal... In: . Pela História do Ceará. Revista do Instituto do Ceará. Fortaleza, p. 115-120, 1934.

TAVARES JÚNIOR, Luiz. O mito na literatura de cordel. Rio de Janeiro: Tempo Brasileiro, 1980. 